\title{
SOCIAL PROTEST MOVEMENT ISLAMIC LAW PERSPECTIVE (Critical Study of the Protest Phenomenon in Indonesia)
}

\author{
Abdul Harris Abbas ${ }^{1}$ \\ Hasyim Aidid ${ }^{2}$ \\ Musafir Pabbabari ${ }^{3}$ \\ Marilang ${ }^{4}$ \\ Alauddin State Islamic University Makassar, Indonesia ${ }^{1,2,3,4}$ \\ emailkorespondensi@gmail.com
}

\begin{abstract}
This study formulates three problems which include: (1) The principles of the social protest movement from the perspective of Islamic law; (2) Methods and techniques for conducting demonstrations from the perspective of Islamic law; (3) The social impact of demonstrations in Indonesia from the perspective of Islamic law. This study uses a qualitative method (descriptiveanalytic). Based on the data source is library research (library research). The approach used is the sociological approach of Islamic law and the siyasah fiqh approach. In the perspective of scientific studies, these two approaches are used to understand the phenomenon of demonstrations in Indonesia based on legal arguments contained in the Qur'an and Hadith, the opinions of fuqahä' and opinions that develop (ijitahād) at a time in life. Muslims. Meanwhile, from a methodological perspective, these two approaches are used to provide an interpretation of the methodology of Islamic law on the concept and practice of demonstrations based on social movement theory and Islamic political theory. The results of this study found that: The principles of the Islamic social protest movement are built on the doctrine of rights and obligations between the people and the rulers in an Islamic state which include: the principle of hisbah; The principle of freedom of expression; The principle of deliberation; and constitutional principles. Based on the method of carrying out the demonstration, there are 2 methods, namely the exclusive method and the inclusive method. Based on the technique of holding demonstrations, there are 3 levels, namely: (1) demonstrations with the ability and strength of the masses; (2) demonstration with verbal ability and strength; (3) protest with the ability of the heart. Through the istislāhi approach, that Islamic law strongly condemns all demonstration activities that cause harm to religion, soul, mind, descendants and property. On the other hand, he strongly supports all demonstration activities that uphold the five maintenances (Maqăsid al-khamsah). That demonstrations are not at all motivated by passion or personal tendencies, let alone to cause damage to the earth. It is an obligation not just an appeal for those who can afford it. The law is fardu kifayah. Turning away from that obligation is the same as carrying oneself That demonstrations are not at all motivated by passion or personal tendencies, let alone to cause damage to the earth. It is an obligation not just an appeal for those who can afford it. The law is fardu kifayah. Turning away from that obligation is the same as carrying oneself That demonstrations are not at all motivated by passion or personal tendencies, let alone to cause damage to the earth. It is an obligation not just an appeal for those who can afford it. The law is fardu kifayah. Turning away from that obligation is the same as carrying oneself
\end{abstract}

Keywords: Social Protest Movement; Demonstration Phenomenon; Islamic law 


\section{PRELIMINARY}

The journey of Islamic law in Indonesia shows that the presence of Islamic law in national law is a struggle for existence. According to the theory of existence, the development of Indonesian law must not ignore the inner values contained in religious teachings. Because Islamic teachings have their own legal teachings, the state is obliged to create new laws derived from Islamic religious law in the national legal order. In the national legal system, religious morals should enter and be in it, and even have a function to influence the teachings and formulation of the law. ${ }^{1}$

About $87 \%$ of Indonesia's population is Muslim. It is almost certain that the perpetrators of anarchic demonstrations are carried out by mostly students and elements of society who are Muslim, or Islamic-based social organizations, who are required to be bound by their religious teachings which are a reflection of values that are believed by the community as an institution in social life. and state (the theory of the shahada or the theory of the creed). ${ }^{2}$

Sociologically it is recognized that society is always changing. Changes in a society can affect the mindset and values that exist in that society. The more advanced the way of thinking of a society, the more open it is to accept social change, advances in science and technology. For religious people, in this case Muslims, this fact can cause problems, especially if these activities are associated with religious norms. As a result, a solution to this problem is needed, so that Islamic law can be proven not to contradict the changing times, advances in science and technology more than that, it can be believed that Islamic law is suitable for every society, wherever and whenever it is located.

In line with the increasing awareness to return to a pure and original religion and the emergence of a desire to harmonize contemporary life with the provisions of the shari'ah, Islamic law in modern times has received a lot of attention both from its supporting community and from other communities that make it an object of study. including the study of demonstrations in Indonesia from the perspective of Islamic law. Departing from the description of the background of the problem above, it can be formulated the main problems of this research, namely: "How is the social protest movement in Indonesia from the perspective of Islamic law, in order to get a complete answer to these main problems, the things that will be described in this paper are related to.

\section{THEORETICAL REVIEW}

\section{A. Demonstration Concept}

Protes is a word adopted from English "Protest" into Indonesian "protest." According to Poerwadarminta, protest has the meaning as a statement of disapproval,

${ }^{1}$ Ichtijanto, Pembangunan Hukum dalam Perspektif Moral, dalam politik Pembangunan Hukum Nasional (Yogyakarta: UII Press, 1992), h.75.

${ }^{2}$ Imam Syaukani,, Rekonstruksi Epistemologi Hukum Islam Indonesia dan Relevansinya Bagi Pembangunan Hukum Nasional (Cet. I; Jakarta: Raja Grafindo Persada, 2006), h. 67-68. 
refuting, denying, refusing, and so on. .3 Protests can be carried out individually or collectively in various forms, such as demonstrations, insubordination, rejection, strikes, petitions, and others. According to Lofland, who compiled the term protest from various dictionaries, the word protest is a noun and a verb that contains meaning; public expression of opinion and usually in the form of defiance; complaints, objections, or expressions of reluctance to an idea or action; a straightforward expression of refusal; declarations by certain parties; declare (something) openly in public; make a formal written rejection declaration; swear; promise to do a mass refusal; put the problem in proportion. ${ }^{4}$ In this context, according to Lofland, the word protest contains the following dimensions: (1) rejection or objection; (2) on something opposite; (3) which has become intolerable; (4) addressed to a person or institution in power; (5) in a crowd and officially; (6) which is done openly; (7) and is based on a feeling of injustice. ${ }^{5}$

Social protest is defined by the word mu'aradah, in which it contains the meaning of muqābalah (to meet; compare), Mudārasah, (study), tafnīd (denial; denial), al-ityān bi al -mukhālif (bringing something contradictory), naqd (criticism), and rafad (rejecting). In this case, social protest is synonymous with the term opposition in Islam. ${ }^{6}$ While the term demonstration is referred to by two terms, namely masīah and muzāharah. Masīah literally means "journey", in the al-Mawrid dictionary it is stated that masirah means march, or long march. ${ }^{7}$ Demonstrations in this concept emphasize action patterns that move and don't stay still in one particular place (parade). Such a pattern is called a dynamic pattern, as opposed to a static pattern, namely actions that are carried out only in silence in one particular place, for example the free pulpit action. That is, demonstrations are not accompanied by boycotts; strike; unrest; and destruction (terror); anarchism, or can also be referred to as a long march, which emphasizes more on patterns of action that move and do not stay still in one particular place (parade).

In In this context, the demonstration that is the focus of the study is a demonstration in the sense of muzāharah. Muzāharah which comes from the word "al-zuhru" which has many meanings including: elevation, and improvement, assistance, victory, and success. ${ }^{8}$ In al-Munawwir's dictionary, al-ijtimā'u al-ihtijajiy is defined as "demonstration", without specifying whether it is anarchic or not. ${ }^{9}$ Even demonstrations are also interpreted as going out with a group of people openly and helping each other

${ }^{3}$ Poerwadarminta, Kamus Besar Bahasa Indonesia (Jakarta: penerbit Pusat Bahasa dan Sastra Indonesia, 1976), h. 776.

${ }^{4}$ Jhon Lofland, Protes: Suatu Studi Tentang Perilaku Kelompok dan Gerakan Sosial, (terj) Luthfi Ashari (Yogyakarta:INSIST Press, 2003), h. 2.

${ }^{5}$ Jhon Lofland, Protes: Suatu Studi Tentang Perilaku Kelompok dan Gerakan Sosial, h. 2.

${ }^{6}$ Lihat, Navīn Abdul Khalik Muștafa, Al-Mu'araḍah fï Fikr al- Siyāsi al-Islāmīi, diterjemahkan oleh Ali Ghufron, Oposisi Islam (Cet. I; Yogyakarta: LKiS, 2012), h. 14.

${ }^{7}$ Rohi Bālbaki, Qāmūs al-Mawrid 'Arabī-Inkilizìi (A Modern Arabic-English Dictionary), (Beirut: Dār al-'ilm Li al-alayīn, 1995)

${ }^{8}$ Anas Muștafa Ḥafternn Abū Aṭa', Dawābiṭ al-Muẓāharāt: Dirasat Fiqhīyah, Magazine, jāmi'ah Damasiq li al-Ulūmi al-Iqtisāadiyah, Number 21 Edition 1 of 2005, p. 456.

${ }^{9}$ Ahmad Warson Munawir, Kamus al-Munawir: Kamus Arab Indonesia, (Surabaya: Pustaka Progressif, 2002), h. 885. 
to realize a common goal. ${ }^{10}$ In practice the concept of muzăharah is identified with the concept of demonstration that we understand today, and sometimes it is accompanied by a boycott; strike; and destruction (terror); and anarchism.

\section{B. The Structure of the Demonstration Movement}

Macioniststates that a social movement is an organized activity aimed at encouraging or inhibiting a social change (encourages or discourages social change). From the definition of a social movement, it can be underlined that there are two main characteristics of a social movement, namely: the existence of organized activities and the existence of goals related to a social change.

Social movement is a form of collective behavior that lasts long enough, is structured, and rational. Some of the characteristics of social movements according to Greene, include:

1. Number of people

2. General purpose to support or prevent a change

3. The existence of a structure with generally recognized leadership, and the existence of an activity that is maintained for a long time. Social movements are relatively more permanent and organized than other types of collective behavior.

According to Tarrow and Tilly, ${ }^{11}$ the only similarity between several formulations regarding the definition of social movement is that social movements are noninstitutional groups of members of society who are not represented and move in opposite directions of interaction with elites or opposition parties. This means that the social movement always consists of a number of individuals who are dissatisfied and willing to make this change then transform into a purposeful collectivity or groups. This uninstitutionalized group then moves vis a vis with the authorities to make changes. However, there are also groups that are organized and mobilized to make changes for the better.

Social movement in basically a manifestation of protesting against a bad situation and trying to change it. Therefore, it is not surprising that Sartono Kartodirdjo said that one type of social movement is a movement to protest against unfair conditions or regulations. ${ }^{12}$

\section{Social Movement Theories}

According to the history of its development, the typology of this social movement is divided into two, namely Old Social Movements and New Social Movements. Several theories are used as an important framework for understanding new social movements, their relevance to social protest movements in Indonesia are: as follows:

${ }^{10}$ Anas Muṣtafa Ḥ̣aftērn Abū Aṭa', Dawābiṭ al-Muẓāharāt: Dirasat Fiqhīyah, Magazine, p. 456.

${ }^{11}$ Charles Tilly, Doug McAdam \& Tarrow, The Dynamic of Contentious (Cambridge: Cambridge University Press. 200), p. 7.

${ }^{12}$ Sarlito W. Saewono, Aksi Mahasiswa Bukan Aksi Massa dalam Dedy Djamaludin Malik, Gejolak Reformasi Menolak Anarki: Kontroversi Seputar Aksi Mahasiswa Menuntut Reformasi Politik Orde Baru (Bandung: Zaman Wacana Mulia. 1998), h. 87. 


\section{Relative Deprivation Theory (Relative Deprivation Theory).}

This concept was developed by Stouffer. According to this theory, a person feels disappointed because of the gap between expectations and reality. People who want a little and then turn out to be only able to get less will feel lower levels of disappointment than people who have gotten a lot but still want more than what they have got. This factor is also triggered by the process of weakening control and tribal traditions which are usually accompanied by an increase in the level of desire. ${ }^{13}$

2. Resource Mobilization Theory.

This theory emphasizes on technical factors not the cause of the emergence of social movements. In today's sociological discipline, the Resource Mobilization Theory is the dominant theoretical framework in analyzing social movements and collective action. According to Cohen quoted by Oman Sukmana, resource mobilization theorists begin their thesis by rejecting attention to the role of feelings and grievances, as well as the use of psychological categories in understanding New Social Movements. ${ }^{14}$

3. The Political Process Theory (the Political Process Theory)

This theory was first formulated by Douglas Mc Adam in 1982 in a book entitled Process and the Development of Black Insurgency 1930-1970. The term the Political Process Theory is often also referred to as the Political Opportunity Approach or Political Opportunity Structure. The Political Process Theory seeks to combine Mass Society Theory, Relative Deprivation Theory, and Recouerce Theory together into a more historical and political perspective. ${ }^{15}$

\section{History of Protests in Islam}

Demonstrations in Islam are called by two terms, namely: masirah and muzāharah. These two terms are not found in the Qur'an or al-hadith. This is because masirah and muzāaharah are new terms used to synonymize the meaning of rallies or demonstrations which have become a modern state tradition. It is difficult to put the term demonstration or demonstration in the perspective of Islamic political fiqh (fiqh al-siyāsah), because the concept of demonstration has no roots in the classical Islamic political tradition. However, this does not mean that demonstrations cannot be found in the Islamic political tradition, because in the context of implementation, actions similar to these demonstrations have made their mark during the time of the Prophet and alKhulafä' al-Rasyidūn.

Examples of demonstrations in the sense of masirah which means long march, or parade: When the Muslims in Mecca were gathering at al-Arqam's house, 'Umar bin Khattāb who was still an infidel suddenly came and asked for permission to enter .Then the Messenger of Allah met him and said he had converted to Islam Spontaneously heard

\footnotetext{
${ }^{13}$ Sarlito W. Saewono, Aksi Mahasiswa Bukan Aksi Massa dalam Dedy Djamaludin Malik, Gejolak Reformasi Menolak Anarki: Kontroversi Seputar Aksi Mahasiswa Menuntut Reformasi Politik Orde Baru (Bandung: Zaman Wacana Mulia. 1998), h. 87.

${ }^{14}$ Oman Sukmana, Konsep Dan Teori Gerakan Sosial (Malang: Intrans Publishing dan DPP IPSPI, 2016), h. 154

${ }^{15}$ David A. Locher, Collective Behavior, p. 264.
} 
takbir all residents of the house. Umar then asked, "aren't we on the truth, O Messenger of Allah? Then why da'wah is still secret?" That's when all the friends gathered and formed two lines, one led by 'Umar bin Khattāa and the other led by Hamzah bin Abdul Muttalib. They then walked neatly towards the Kaaba in Masjid al-Haram and the disbelievers of Quraysh witnessed it. ${ }^{16}$ Another example, the residents of the city of Medina went out to protest when welcoming the arrival of the Prophet Muhammad, in the event of Hijrah; The Muslims who were led directly by the Prophet came out to protest to welcome Mut'ah's army on the outskirts of Medina. ${ }^{17}$

The tragedy of the demonstration which transformed into the impeachment and assassination of caliph 'Uthman Bin Affan subsequently by the Islamic world is known as al-Fitnah al-Kubrā (the Great Disaster). This incident had an impact on the political polarization of Muslims and on the face of subsequent Islamic social movements. In the first perspective, after the killing of 'Usman bin 'Affan, the Muslims split into three groups: the Ali bin Abi Talib group, the Mu'awiyah bin Abi Sofyān group, and the Mu'awiyah bin Abi Sofyān group. moderate/neutral who does not favor one of the two groups. ${ }^{18}$ The presence of these three groups, marked the political feud in the next historical period, especially in the struggle for power of Islamic leadership. So alSyahrastāni, in his book Al-Milal wa al-Nihal says that the biggest dispute among the people is the dispute over imamah (leadership), because a sword is never drawn in Islam for religious reasons as (as often) drawn up because of the priesthood in every age). ${ }^{19}$

In the second perspective, which is a consequence of the first perspective. The face of Islamic social movements that describe the relationship between the people and the authorities will always be marked by the presence of an opposition movement. Social protests and demonstrations will be a potential means to voice 'amar ma'rüf nahì munkar by the people as well as the opposition to injustice and arbitrariness of the authorities.

\section{RESEARCH METHODOLOGY}

This study uses a qualitative method (descriptive-analytic). Based on the data source is library research (library research). The approach used is the sociological approach of Islamic law and the siyāsah fiqh approach. In the perspective of scientific studies, these two approaches are used to understand the phenomenon of demonstrations in Indonesia based on legal arguments contained in the Qur'an and Hadith, the opinions of fuqahā' and opinions that develop (ijitahād) at a time in life. Muslims. Meanwhile, in a methodological perspective, these two approaches are used to provide an interpretation of the methodology of Islamic law on the concept and practice of demonstrations based on social movement theory and Islamic political theory.

${ }^{16}$ Jalāl al-Dīn al-Suyūțī, Tārikh al-Khulafā'i (t.tp: Maktabah Nizar Musṭafa al-Bazi, 1425 H), p. 114.

${ }^{17}$ Anas Muștafa Ḥaftern Abū Aṭa', Dawābiṭ al-Muẓāharāt: Dirasat Fiqhīyah, Magazine, Jami'ah Damasiq li al-Ulūmi al-Iqtișādiyah, Number 21 Edition 1 of 2005, p. 456.

${ }^{18} \mathrm{Abū}$ al-Fath Muḥammad bin Abd al-Karīm al-Syahrastānì, Al-Milal wa al-Niḥal (Beirut: Dār al-Kutūb al-Ilmìyah, tt ), h. 136-137

${ }^{19} \mathrm{Abū}$ al-Fath Muhammad bin Abd al-Karim al-Syahrastānī, Al-Milal wa al-Nihal, p. 13. 


\section{RESEARCH RESULTS AND DISCUSSION}

\section{A. The Principles of Demonstration}

The principles of this demonstration refer to the doctrine of rights and obligations between the people and the rulers in an Islamic state and the legal basis for the permissibility of demonstrations in Islam, namely that Islam is within itself a democracy, very close to Islam and its substance is in line with Islam, therefore fully accepting it. democracy as something universal. ${ }^{20}$ The principles in question include:

1. Hịbah principle

Hisbah is an individual or collective obligation to intervene in an effort to amar ma'ruf nahi munkar. The correlation between amar ma'rü nahi munkar and demonstrations can be seen in two orientations: first, 'amar ma'rü nahi munkar is the duty of the government and members of the council in exercising the political power of their government; the government is obligated to uphold the principles ordered by religion, and prohibit according to what is prohibited by religion. Second, at the same time, he is a proponent and supporter of the legality of the opposition. ${ }^{21}$

Showtaste in the concept of hisbah refers to several arguments including, QS. Ali Imrān/3:104 and 110:

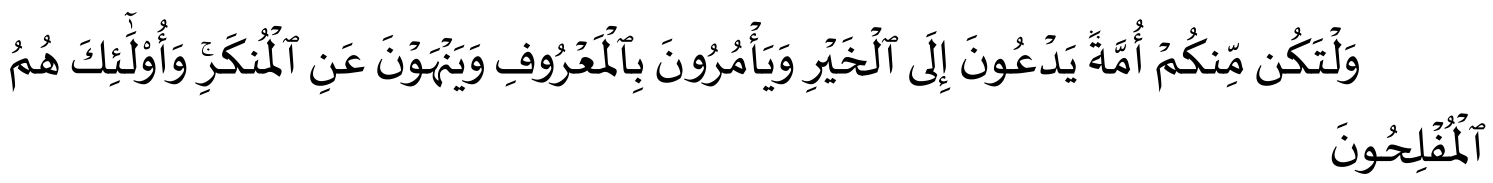

The translation:

"And let there be among you a group of people who call to righteousness, enjoin the right and forbid what is evil, they are the lucky ones. "22

According to the General Chairperson of the FPI, Habib Muhammad Rizieq Syihab, the battlefield of Islam consists of three parts, namely: Da'wah, hisbah, and jihad.In the field of struggle, hisbah is an effort to enforce 'amar ma'rü nahi munkar. Amar makruf is in the form of a clear call and instruction to the community to do good. The Prophet SAW, when conveying amar makruf like the voice of the command of the combat troops, his voice was loud and his eyes looked red. If the battlefield of da'wah is required to be gentle, amar makru'f is firm, while nahi munkar must be even more firm. The Prophet once broke liquor barrels, punched drunk people in the market for disturbing the residents around him, including orders to burn down the dirär mosque. According to

\footnotetext{
${ }^{20}$ Darussalam Syamsuddin, Democracy in the Frame of Islamic Political Thought (Cet. I; Makassar: Alauddin Press, 2012), p. 6.

${ }^{21}$ See, Navīn Abd al-Khalik Muṣtafā, Al-Mu'araḍah fî Fikr al-Siyāsi al-Islāmī, translated by Ali Ghufron, Islamic Opposition (Cet. I; Yogyakarta: LKiS, 2012), p.125.

${ }^{22}$ Ministry of Religion of the Republic of Indonesia. Al-Qur'an and its translation, Revised Edition, (Surabaya: Karya Agung, 2006), p. 79.
} 
him, mosques that were built to divide people were burned, let alone other places of immorality. his assertion in this regard, ${ }^{23}$

Somethe fiqh doctrine that emphasizes the legality of demonstrations is, according to al-Mawardi, that the source of the power of the head of state is based on an agreement between the head of state and his people (social contract). From this agreement, mutual rights and obligations were born between the two parties, therefore, the people who have given power and some of their rights to the head of state have the right to lower the head of state, if deemed unable to run the government in accordance with the mutually agreed agreement. ${ }^{24}$

\section{The Principle of Freedom of Opinion}

HistoryIslamic government has demonstrated the principle of freedom of thought and opinion. Khalifah Abū Bakar al-Ṣiddiq openly in public said "-if I behave well, help me. But if I do wrong, lead me to the right path. Truth is holy and wrong is treason." Likewise, after being sworn in as caliph, 'Umar ibn al-Khattāb addressed his people: "My people, whoever sees something wrong in me, let you straighten it out". Immediately Huzaifah ibn al-Yamān replied, "By Allah, O Amir al-mu'minin, if only I found something crooked and distorted in you, then I myself would straighten it out with this sword of mine". Responding to this person, 'Umar said, "Praise be to Allah who has made a person among this Ummah who wants to straighten out the crookedness of 'Umar with his sword". ${ }^{25}$

This principle requires people to firmly state the truth without fear of anyone, even if it concerns the government. ${ }^{26}$ As the hadith of the Prophet Muhammad SAW:

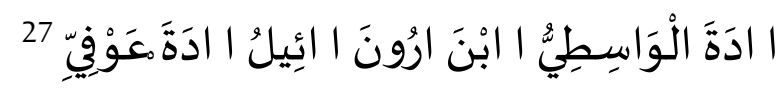

Meaning:

"The most important jihad is speaking the truth in front of an unjust ruler or government.'

Show Rasa does not mean to take up arms against the government, but is a way to advise the government and prevent it from committing evil deeds and injustice to the people. ${ }^{28}$

${ }^{23}$ Habib Muhammad Riziq Shihab, Dialog FPI-Amar Makruf Nahi Munkar (Cet. I; Jakarta: Ibnu Saidah, 2008), h. 43-48.

${ }^{24}$ Abū al-Ḥasan Ali Muhammad Ibn Ḥabīb al-Mawardi, Al-Ahkāmu al-Sultānīyah (Beirut: Dār al-Fikr, 450 H), h. 17-19; Muhammad Iqbal, Fiqh Siyasah: Konstektualisasi Doktrin Politik Islam (Cet. I; Jakarta: Kencana, 2014), h. 127

${ }^{25}$ Abdurrahman Aḥmad al-Bakrī, Min Hayat Khalifah 'Umar bin Khațtab. Juz I (Beirut: al-Isyād, tth), p. 126-128. Quoted by. Ridwan HR., Political Fiqh: Ideas, Hopes and Realities (Cet. I; Yogyakarta: FH UII Press, 20017), p. 41.

${ }^{26}$ Wahbah al-Zuhaili, Al-Fiqh al-Islām wa Adillatuh (Beirut: Dār al-Fikr, 1409 H), p. 712-722.

${ }^{27}$ Abū Dāwud Sulaimān bin al-Asy'as Ibn Syaddād al-Azadi Al-Sijistānī, Sunan Abū Dāwud, Juz 3 (Beirut: Dār al-Fikr, 1968), p. 128.

${ }^{28}$ Ali Muhammad al-Șallabi, Fikih Tamkin: Panduan Meraih Kemenangan dan Kejayaan Islam, diterjemahkan oleh Samson Rahman (Cet. I: Jakarta; Pustaka Pelajar, 2006), h. 265. 


\section{Deliberation Principle}

discussion is the most fundamental and most significant pillar of Islamic governance, that deliberation is the essence of Islamic teachings that must be applied in the social life of Muslims, just as hisbah is the most urgent task that is equally carried out by individuals and society.

The essence of Deliberation is to provide opport unities for community members who have the ability and right to participate in making binding decisions, either in the form of legal rules or in political policies. ${ }^{29}$ The majority of scholars are of the opinion that the law of deliberation is obligatory. ${ }^{30}$ The basis of this principle comes from QS. Ali Imrān/3:159:

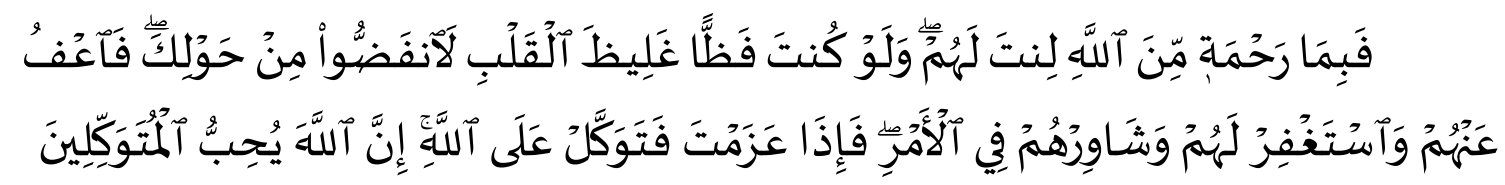

The translation:

"So it is because of the mercy of Allah that you are gentle with them. if you were hard-hearted and harsh-hearted, they would have distanced themselves from all around you. Therefore forgive them, ask forgiveness for them, and consult with them in this matter. Then when you have made up your mind, then put your trust in Allah. Verily Allah loves those who put their trust in Him. "31

the principle of deliberation must be on the tabayyun agenda with the government or authorities. What also needs to be underlined in this cycle is based on the verse above, "-So it is because of Allah's mercy that you are gentle with them. If you were hard-hearted and rough-hearted, they would have kept themselves away from those around you," that the order for deliberation (tabayyun) is preceded by several attitudes that must be possessed by people who will conduct deliberation, namely being gentle, giving forgiveness, and asking forgiveness for every mistake. in deliberation. A stubborn attitude, let alone accompanied by stubbornness, will not result in an agreement as the goal of deliberation. Therefore,

\section{Constitutional Principles}

Indonesia is a country that adheres to a democratic system. Choice of system democracy is based on the argument that democracy is compatible with Islam. According to Darussalam Syamsuddin, the thoughts of Islamic theorists about democracy in Indonesia are mapped into two categories. First, the group that accepts but acknowledges the differences. This group was pioneered by Muhammad Nasir, followed by Jalaluddin Rakhmat, Deliar Noer and AM Fatwa. This group distinguishes democracy from the West with Islam. According to them, in Islam there are values and principles of democracy. For example, al-'is, al-musawā, al-syūrā', and others. Although

\footnotetext{
${ }^{29}$ Abdul Muin Salim, Konsep Kekuasaan Politik Islam dalam al-Qur'an (Cet.I; Jakarta: Raja Grafindo Persada, 1994), h. 259..

${ }^{30}$ Abd al-Qadir Abd al-Qadir ‘Audah, al-Islāmu wa Auḍā'unā al-Siyāsìyah (Kairo: Dār al-Kutūb al-Arabi 1951), h.150; Mahmūd Bablili, al-Syura’ fi Islām (Cet. I; Beirut: Dār al-Irsyād, 1969), h. 9-11..

${ }^{31}$ Departemen Agama RI. Al-Qur'an dan Terjemahnya, Edisi Revisi, h. 90.
} 
these values and principles have similarities with Western democracies, their application is different. While the second group, is a group that accepts democracy completely. Among the ringleaders were Nurcholish Madjid, Amien Rais, Ahmad Syafi'i Ma'arif, Munawir Syadjali and Abdurrahman Wahid. This group sees that Islam in itself is a democracy, and therefore fully accepts democracy as something universal. ${ }^{32}$

In general, Muslim intellectuals agree with the use of the term Pancasila democracy. According to Hazairin, Pancasila democracy is an abbreviation of the fourth precept, namely "Democracy (populist: Writers) led by wisdom in deliberation/representation." However, to discuss Pancasila democracy, it is not enough to only discuss the fourth precept. -The first precept, divinity in the One and Only God has a special position, because it transcends human creation, while the other comes from history and human experience, which produces a normative culture in material and spiritual life. ${ }^{33}$

obedience Protesters against Law No. 9 of 1998 on Freedom to Express Opinions in Public is an obligation and proof of obedience as a people to the government. QS. alNisā'/4:59:

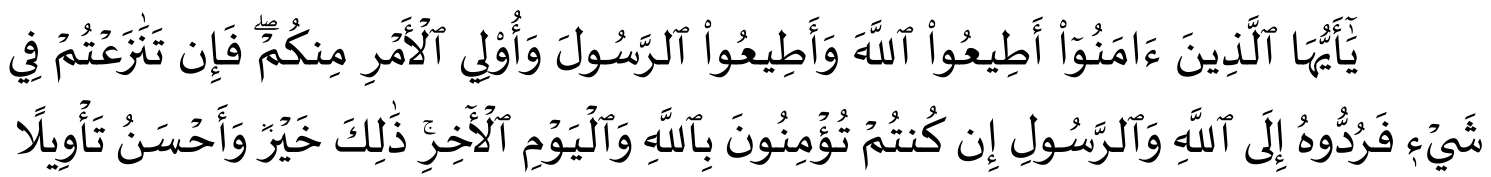

Translate:

"Hi those who believe, obey Allah and obey the Messenger (His), and the ulil amri among you. Then if you disagree about something, then return it to Allah (the Quran) and the Messenger (his Sunnah), if you truly believe in Allah and the Last Day. that is more important (for you) and better as a result. ${ }^{\prime 34}$

\section{B. Demonstration Implementation Techniques}

By In general, the technique of holding demonstrations from the perspective of Islamic law is divided into 2 methods, namely the exclusive method and the inclusive method:

The exclusive method, the exclusive method is a demonstration method carried out without accompanying the masses, in the form of criticism or suggestions (advice) directly to the government or authorities in a closed manner. This method is based on the hadith of the Prophet Muhammad:

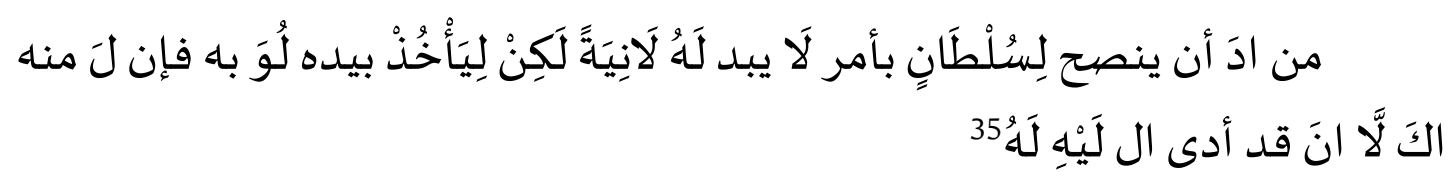

${ }^{32}$ Darussalam Syamsuddin, Demokrasi dalam Bingkai Pemikiran Politik Islam, h. 10-11.

${ }^{33}$ Hazairin, Demokrasi Pancasila (Cet. VI; Jakarta: Rieneka Cipta, 1990), h. 15-17..

${ }^{34}$ Departemen Agama RI. Al-Qur'an dan Terjemahnya, Edisi Revisi, h. 144.

${ }^{35} \mathrm{Ab}$ 'Abdullāh Aḥmad Ibn Hanbal, Musnad Aḥmad ibn Hanbal, Juz 3, Hadith no. 14792 (Beirut: Maktabah al-Islāmī, 1978), p. 403. 


\section{Meaning:}

"Whoever wants to advise the ruler on a problem, let him not show it openly. However, let him take his hand and be alone with him. If he accepts (the advice) then that is good, but if he does not then he has fulfilled his obligation to give advice."

Inclusive Method The inclusive method is a demonstration carried out by involving the masses and carried out demonstratively in public. This method is based on the hadith of the Prophet Muhammad:

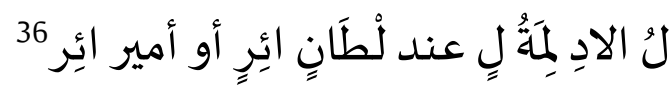

Meaning:

"The most important jihad is speaking the truth in front of an unjust ruler or government."

At the level of implementation of the demonstration, its relevance to the concept of amar ma'ruf nahi munkar, there is one argument that is used as a reference, namely the hadith of the Prophet Muhammad:

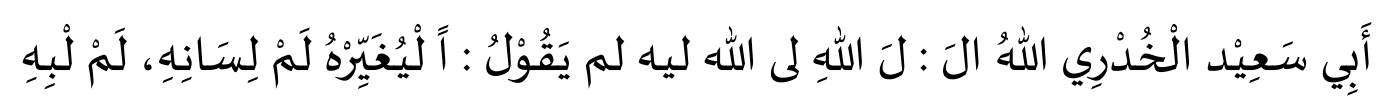

Meaning:

"Whoever sees an evil, then let him change it with his hand, if he cannot, then with his tongue, and if he cannot, then with his heart, and that is the weakest faith."

At the level of implementation of the demonstration, its relevance to the concept of amar ma'rüf nahi munkar, there is one argument that is used as a reference, namely the hadith of the Prophet Muhammad:

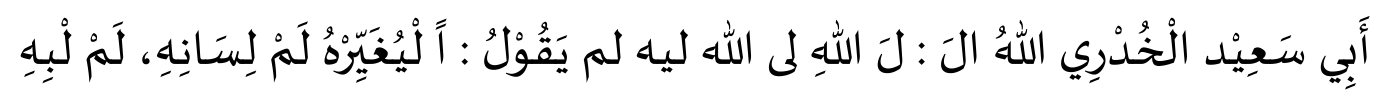

Meaning:

"Whoever sees an evil, let him change it with his hand, if he is not able, then with his tongue. and if not able then with his heart and that is the weakest faith."

In text, this hadith is an important guide in the implementation of the demonstration from the perspective of Islamic law.

\footnotetext{
${ }^{36}$ Abū Dāwud Sulaiman̄n bin al-Asy'as Ibn Syaddād al-Azadī Al-Sijistānī, Sunan Abū Dāwud, Juz 3 (Beirut: Dār al-Fikr, 1968), h. 128.

${ }^{37}$ Ibn Majah, Sunan Ibn Majah, Juz II (Beirut-Lebanon: Dār al-Kutūb al-Ilmiyah, t.th), p.1330.

${ }^{38}$ Ibn Majah, Sunan Ibn Majah, Juz II (Beirut-Lebanon: Dār al-Kutūb al-Ilmiyah, t.th), p.1330.
} 
Abdul Harris Abbas, Hasyim Aidid,

Musafir Pabbabari, Marilang Marilang

\section{Social Impact of Protests in Indonesia}

Demonstrations as a manifestation of social protest are social movements identified as movements born from a group of individuals to fight for their aspirations and demand social change. Demonstrations are carried out as a form of manifestation of social protest or opposition to policies implemented by a party or can also be carried out as an effort to politically suppress group interests for more pluralistic interests.

Demonstrations in the perspective of New Social Movements Theory are described as mass movements that are clearer or with positive aims, which are not merely because of dissatisfaction or emotion to destroy the socio-political order, but are rational and deliberate movements to initiate social and political change. ${ }^{39}$

The effectiveness of demonstrations as social control and as a driver of postreform social change in Indonesia can be seen in the demonstration data collected over a ten year period, showing that reformative demonstrations are quite effective and have a positive impact on social change desired by the people. The degree of effectiveness is also closely related to the issues being fought for, the use of creative methods, massive mass support and the presence of rational figures and political support. The success of most student demonstrations, as well as in the Defending Islam Action demonstration, is due to the fact that this group is younger to mobilize, and has an established communication network, there are members with leadership abilities, and traditional participation from its members. Other than that, in this group there are leaders, members, meeting places, routine activities, social chains, and shared beliefs, symbols and language. A leader in this social movement must focus his attention on the issues of mobilization, discontent, tactical choices, and the community and movement infrastructure necessary for a social movement to succeed. ${ }^{40}$ Thus, the demonstration has participated in encouraging social change for the better for the lives of Muslims, at least determining what should be considered good and bad; what are the commands, recommendations, impositions, and prohibitions of religion. All of this is in line with the spirit of amar ma'rüf nahi mungkar which was initiated to fight injustice, prevent damage, and restore power to the people and free them from the confines of tyranny and dictatorship.

\section{Law Rally}

In the Qur'an there are ten verses that use the sentence amar ma'rüf nahi munkar, namely: 1) Amar ma'rūf nahī munkar is God's command. QS Ali Imran/3:104, 2) Amar ma'rüf nahi munkar is the only reason Muslims become the best ummah QS Ali Imran/3:110, 3) Amar ma'rüf and nahi munkar are call to do good, not hatred let alone do damage and destruction on earth, QS. Ali Imran/3:114:4) Amar ma'rūf nahī munkar is the duty of the Prophet Muhammad SAW., and his followers, QS. Al-A'rāf/7:157, 5) Amar ma'rüf nahi munkar is a social and collective worship as well as a guarantee of Allah's mercy upon him, QS. Al-Taubah/9:71, 6) A person cannot be called perfect in his faith only by repenting, worshiping, bowing and prostrating without doing amar ma'rūf nahī evil ; QS. Al-Taubah/9:112,7) Ignoring amar makrūf nahi munkar is an attitude of

\footnotetext{
${ }^{39}$ Nur Sayyid Santoso Kristeva, "Politics and the State” part 2. in Petjut.id, http//:petjut.id/2019/ 07/07/part-2 (15 June 2020).

${ }^{40}$ David A. Locher, Collective Behavior (New Jersey: Prentice Hall, 2002), p. 261.
} 
disobedience to Allah, QS. Al-Maidah/5:78-79, 8) Amar ma'rü nahī munkar is the difference between believers and hypocrites, QS. Al-Taubah/9:67, 9) Amar makrü nahi munkar is a condition after prayer and zakat, QS. Al-Hajj/22:41, 10) The enforcers of makrü nahi munkar must be patient to accept hatred and suffering, QS. Luqman/31:17. munkar must be patient to accept hatred and suffering, QS. Luqman/31:17. munkar must be patient to accept hatred and suffering, QS. Luqman/31:17.

\section{CONCLUSION}

The relationship between the people and the rulers is often transformed in the form of social protest movements or demonstrations. From the perspective of Islamic law, demonstrations are built based on several principles, including: (1) the Hisbah principle; (2) the principle of freedom of opinion (Hurriyah al-fikr wa al-qaul); (3) Deliberation Principle; and (4) Constitutional Principles. These four principles emphasize that demonstrations are part of efforts to enforce amar makrūf nahi munkar, which requires protesters to expressly state the truth without fear of anyone, by prioritizing the agenda of deliberation, tabayyun, and mutual respect. In its implementation, it must be based on religious and state norms. The demonstration can be carried out through 2 methods, namely First, the exclusive method is a demonstration method that is carried out without accompanying the masses, in the form of criticism or suggestions (advice) directly to the government or authorities in a closed manner. Second, the inclusive method is a demonstration carried out by involving the masses and carried out openly. In the demonstration technique, there are three paths and levels in the demonstration which are closely related to the meaning of ability (istițā'ah), namely: First, demonstration using the ability and strength of the masses. Second, demonstrations using the logic of discussion and lectures to express opinions about an evil, as well as the desire to change it. Third, demonstrations using the heart, meaning the inability to change an injustice in the form of demonstrations using hands and verbally. So that it is only limited to his rejection and criticism by using his heart. The first and second options show active demonstrations, while the third option shows passive protests. Islamic law legitimizes demonstrations as a means of promoting social change for the better. Demonstrations are interpreted as one of the forums and forms of the people's hisbah rights to the authorities, or the people's ability to supervise the country and use their political rights in opposition, and fight in defense of the public good. From the analysis of the phenomenon of demonstrations in Indonesia conducted by students, workers, and the Islamic Defense Action, it was found at least 4 (four) fundamental violations, namely: (1) causing traffic jams (2) Use of unethical words, (3) destruction of public facilities, (4) and the impact on loss of life and property. And these four basic things, are very contrary to the purpose of Islamic law (maqā .). șid al-Shari'ah) which is to create benefit and prevent harm which includes efforts to maintain religion, soul, mind, lineage, and property. The legal discovery methodology used is sourced from the Qur'an, and hadith as well as the opinions of the fuqahā. While the legal analysis technique based on the istiṣlạimethod with the approach of fiqh principles, mașlahah al-mursalah, and maqāșid al-syari'ah, formulates that the law of demonstration in Indonesia is permissible. (permissible), can even develop into sunnah or obligatory, depending on the qarinah-qarinah (situation and conditions). Islamic law emphasizes that sanctions or sins are only imposed on the anarchist violator, not also on other people who do not commit the violation. and vice versa, 


\section{BIBLIOGRAPHY}

Agama, Kementrian RI, Al-Qur'an dan Terjemahnya Surabaya: Halim, 2014.

Abd al-Qadir Abd al-Qadir 'Audah, al-Islāmu wa Auḍ̄' unā al-Siyāsìyah Kairo: Dār alKutūb al-Arabì 1951, h.150; Mahmūd BabliГi, al-Syura' fi Islām Cet. I; Beirut: Dār al-Irsyād, 1969.

Abdul Muin Salim, Konsep Kekuasaan Politik Islam dalam al-Qur'an Cet.I; Jakarta: Raja Grafindo Persada, 1994.

Abdurrahman Ahmad al-Bakrī, Min Hayat Khalifah 'Umar bin Khațab. Juz I Beirut: alIsyād Dikutip oleh. Ridwan HR., Fiqih Politik: Gagasan, Harapan dan Kenyataan Cet. I; Yogyakarta: FH UII Press, 20017.

Abū 'Abdullāh Aḥmad Ibnu Hanbal, Musnad Aḥmad ibn Hanbal, Juz 3, hadis no. 14792 Beirut: Maktabah al-Islāmī, 1978

Abū al-Ḥasan Ali Muhammad Ibn Ḥabīb al-Mawardi, Al-Aḥkāmu al-Sulțāniyah Beirut: Dār al-Fikr, 450 H, h. 17-19; Muhammad Iqbal, Fiqh Siyasah: Konstektualisasi Doktrin Politik Islam Cet. I; Jakarta: Kencana, 2014

Abū Dāwud Sulaimān bin al-Asy'as Ibn Syaddād al-Azadī Al-Sijistānì, Sunan Abū Dāwud, Juz 3 Beirut: Dār al-Fikr, 1968

Ahmad Warson Munawir, Kamus al-Munawir: Kamus Arab Indonesia, Surabaya: Pustaka Progressif, 2002

AҐi Muhammad al-Ṣallabi, Fikih Tamkin: Panduan Meraih Kemenangan dan Kejayaan Islam, diterjemahkan oleh Samson Rahman Cet. I: Jakarta; Pustaka Pelajar, 2006

Anas Mustafa Ḥusaīn Abū Aṭa’, Dawābit al-Muzāharāt: Dirasat Fiqhīyah, Majalah, jāmi'ah Damasiq li al-Ulūmi al-Iqtịsādiyah, Nomor 21 Edisi 1 tahun 2005

Charles Tilly, Doug McAdam \& Tarrow, The Dynamic of Contentious Cambridge: Cambridge University Press. 2001.

David A. Locher, Collective Behavior New Jersey: Prentice Hall,2002.

Departemen Agama RI. Al-Qur'an dan Terjemahnya, Edisi Revisi, Surabaya: Karya Agung, 2006

Habib Muhammad Riziq Shihab, Dialog FPI-Amar Makruf Nahi Munkar Cet. I; Jakarta: Ibnu Saidah, 2008.

Hazairin, Demokrasi Pancasila Cet. VI; Jakarta: Rieneka Cipta, 1990 .

Ibnu Majah, Sunan Ibnu Majah, Juz II Beirut-Libanon: Dār al-Kutūb al-Ilmiyah, t.th,

Ichtijanto, Pembangunan Hukum dalam Perspektif Moral, dalam politik Pembangunan Hukum Nasional Yogyakarta: UII Press, 1992.

Imam Syaukani,, Rekonstruksi Epistemologi Hukum Islam Indonesia dan Relevansinya Bagi Pembangunan Hukum Nasional Cet. I; Jakarta: Raja Grafindo Persada, 2006. 
Jalāl al-Dīn al-Suyūți, Tārikh al-Khulafá'i t.tp: Maktabah Nizar Musțafa al-Bazi, 1425 H.

James C. Scott, Weapon of the Weak: Everyday Form af Peasant Resistance, diterjemahkan oleh A. Rahman Zainuddin, dkk., Senjata Orang-Orang Yang Kalah Cet. I; Jakarta: Yayasan Obor Indonesia, 2000.

Jhon Lofland, Protes: Suatu Studi Tentang Perilaku Kelompok dan Gerakan Sosial, terj Luthfi Ashari Yogyakarta:INSIST Press, 2003.

Darussalam Syamsuddin, Demokrasi dalam Bingkai Pemikiran Politik Islam Cet. I; Makassar: Alauddin Press, 2012 .

Navīn Abd al-Khalik Muṣtafā, Al-Mu'araḍah fî Fikr al- Siyāsi al-Islāmī, diterjemahkan oleh Ali Ghufron, Oposisi Islam Cet. I; Yogyakarta: LKiS, 2012

Nur Sayyid Santoso Kristeva, "Politik dan Negara" part 2. dalam Petjut.id, http//:petjut.id/ 2019/ 07/07/part-2 15 Juni 2020.

Oman Sukmana, Konsep Dan Teori Gerakan Sosial Malang: Intrans Publishing dan DPP IPSPI, 2016 .

Poerwadarminta, Kamus Besar Bahasa Indonesia Jakarta: penerbit Pusat Bahasa dan Sastra Indonesia, 1976.

Rohi Bālbaki, Qāmūs al-Mawrid 'Arabī-Inkilizī A Modern Arabic-English Dictionary, Beirut: Dār al-'ilm Li al-alayīn, 1995.

Sarlito W. Saewono, Aksi Mahasiswa Bukan Aksi Massa dalam Dedy Djamaludin Malik, Gejolak Reformasi Menolak Anarki: Kontroversi Seputar Aksi Mahasiswa Menuntut Reformasi Politik Orde Baru Bandung: Zaman Wacana Mulia. 1998.

Wahbah al-Zuhaili, Al-Fiqh al-Islām wa Adillatuh Beirut: Dār al-Fikr, 1409 H. 